\title{
THE EUROPEAN COURT OF HUMAN RIGHTS AND THE CYPRUS PROBLEM
}

\author{
Dr. Yusuf AKSAR
}

\begin{abstract}
The European Court of Human Rights (ECHR) in its recent decisions regarding the Cyprus problem such as the Loizidou v. Turkey and Case of Cyprus $v$. Turkey finds Turkey responsible for the current situation in the Island. According to the Court, Turkey violates the rights of the Greek Cypriots were living in the northern part of Cyprus before the military intervention of Turkey took place in 1974. Such violations include inhuman treatment of the families of missing Greek Cypriots, denying some 180.000 Greek Cypriots the right to return to their homes, failure to compensate for loss of property and interference with freedom of religion. Finding Turkey responsible instead of the Turkish Republic of Northern Cyprus (TRNC) is based upon the fact that the TRNC was not an independent State and not even recognised by the international community. This way of application of the rules of international law by the ECHR can be strongly criticised on the ground that it does not give any weight to the causes and effects of the events which took place in Cyprus in 1963 to 1974 , and also to the factors which lead the Turkish Cypriots to establish their own independent States. When the recent history of Cyprus is examined it can clearly be seen that the legal status of the TRNC is not any less legal than its Greek Cypriot counterpart with regard to its statehood and recognition in international law. This paper examines the judgements of the ECHR in the light of the historical background of the Cyprus problem, and of the legal status of the TRNC in relation to its statehood and its non-recognition in international law.
\end{abstract}

() Yusuf Aksar (LLB Ankara Univ. Law Dep.). (LLM Sheffield Univ. Law Dep.), (PhD Bristol Univ. Law Dep.). Assistant Professor of Public International Law at the Department of International Relations. Karadeniz Technical University, Trabzon-Turkey. The Author would like to thank to Professor John G. Merrills (at the Sheftield University Law Department) for his comment on the preparation of this paper. 


\section{The European Court of Human Rights and the Cyprus Problem}

\section{Introduction}

The European Cout of Human Rights (ECHR) has been delivering judgements in which Turkey is found responsible for the current situation in

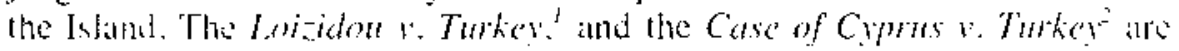
the main accisions in this regard and it is likely to follow by move citses which will he brought before the ECHR. According to these judgenents. Tukey violates the human righis of the Greek Cypriots living in the north of the Istiand before the military intervention of Turkey took place in 1974. In the vicw of the Court, among olhers. Turkey is guily of: failing to invextigate the deaths of about 1.500 people who disappeared in the military intervention, inhuman treament of the families of missing Grect Cypriots. denying some 180.600 Greek Cypriots the right to return to their homes. failure to compenate for loss of property and interference with fredom of religion.

When the view deployed by the ECHR in refation to the Cyprus Case is examined it can tasily be seen that it is not in compliance with the rules of intemational ba and more importanly inconsistent with the realities of the Istand. The judgements are politically motivaled and wholly innores the Cyprus problem. The judgements were based on the lact that the Turkish Republic of Northern Cypres (TRNC) is not legally established and also not recoenised by the international community an an independent State. Moreover, since Turkey exercises effective overall control of nothern Cyprus through its military presence, it should be responsible for the alleged violations of human rights there. This way of understanding and the application of the rules of international kw does not give any weight to the calses and effects of the events which took place in Cyprus from 1963 to 1974, to the lactors which lead the Turkish Cypriots to establish their own independent Stintes.

The sim of this paper is to challenge the legality of the ECHR judgements in the light of the rules of international law. To that end, firsty, the Cyprus problem and the reasons for the establishment of the TRNC will be briefly explatined. Secondly, the concept of statehood and recoentition of at State and. in this sense the TRNC case, will be discussed. Lastly. the decisions of the ECHR will be assessed.

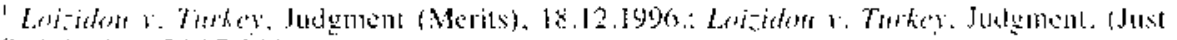

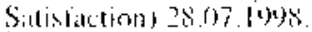

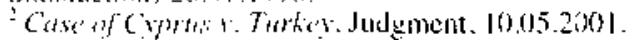




\section{Historical Background to the Cyprus Problem}

The Island of Cyprus, situated 40 miles from the south of Turkey, and approximately 500 miles from the south-east of the Greek mainland, hats an area of 3.572 square miles and is the third largest island in the Mediterranean Sea. According to the census of 1960 the population of Cyprus was 573.566 , consisting of 441.656 Greeks, 104.942 Turks, and 26.968 Maronites, Armenians. Latins and other races. The population is currently estimated to be about 700.000 of which 24 per cent of that population is thought to be Turkish Cypriots. This is not the definite population of Cyprus, since an island-wide census of Cyprus has not been conducted since $1960 .^{3}$

Because of its strategic position Cyprus has been under the influence of different races and religions from the earliest days of its history. In history, the Island of Cyprus had been a part of the Persian, Roman and Byzantine empires. It became a Frankish Kingdom in 1193, in 1489 it was a Venetian dependency, and in 157I the Ottoman Empire conquered the Island, but during its history a "Cypriot nation" has never been created. ${ }^{+}$In that time and to the present day, there have been two major communities which are Greek Cypriols who belong to the Greek Orthodox Church and speak Greek and Turkish Cypriots who are Moslems and speak Turkish. ${ }^{5}$ Under the Ottoman rule, privileges and freedoms were given to the Orthodox Church. There was no hostility between the Greek and Turkish populations, however they did not mix much socially. Intermarriage between these two communities is not allowed. They have guarded their cultural and national heritages. Each community has regulated its own education system in its own language?

On 4 June 1878 the Ottoman Empire and Britain signed a Convention giving Britain the right to occupy and rule the Jsland, although not legally possess it. ${ }^{8}$ The main reason for this was to protect the Ottoman Empire from Russia." During the first World War, Britain amexed the Island (5 November 1914). Until the Treaty of Lausanne in 1923, this situation was

\footnotetext{
"Necatigil. Z.. M., The Cyprus Qucstion and the Turkish Position in Intenational Law. (hereinafter The Cyprus Qtie'stirm), 2nd edition.. Oxford: Oxford University Press. 1993, pp. I.2.

Ertekun. N., M., "The Historical Background of the Cypriot Turkish Declaration of Independence. 15 November 1982". (hereinalter "The Historical Background"), (Winter 1992-94) 6 International Jounul of Turkish Studies. p. 187.

Necatigil. The Cyprus Question. p. 2.

"Dodd. C. . H. "Historical Introduction", in the Political Seriat and Ecmomic Deretopment of Northern Cyprus. (ed. C. H. Dodd). Huntingdon: The Eothen Press, 1993, p. 2.

${ }^{7}$ Necatigil, The Cyprus Question, p. 2.

"Ibid.

"Dodd, p. 2.
} 
not recognised by Turkey. In addition to Turkey's acceptance. Grece also agreed with the Treaty of Lausame that Cyprus should he under the British sovereinty." The British had to deal with two major political problems on the lsland. The first one was the idea of enosis (anion with Greece) and the second one was to keep the two con munities in harmony. In particular, the problem of keeping two communities in harmony was very dillicult, due to the Turkish Cypriots beginning to respond to enosis." The concept of anosis has developed rapidly from the 19.30's in the Greak Cypriot community. In the 1959 's. as a result of Greece's support on the international scenc. the demind lor roosis has emerged with new foree, led by the Archbishop Makarios." On 15 January 1950, a plebiscite in churches was held by the Greek Cypriot Orthodox Church, anc the majority of Greeks voted in fasour of chesis. Alter Makarios was elected Archbishop. he took the following oath: "I take the Holy oath that I shall work for our national aspirations and shall never waver from our policy of annexing Cyprus to mother Grece"." In order to achieve this purpose. a terrorist organisation. known as the EOKA (Ethmiki Organosis Kyprion Agoniston) was established under the leadership of Colonel George Grivas. ${ }^{15}$ This terrorist movement wats primarily directed against the colonial power. ${ }^{16}$ At the same time the Turkish Cypriol commenty set up an anti-terrorist organisation whose name wats Volkam. In 1957 this movement took the name of Tatk Mukatemet Teskilati (Turkind Resistince Organisation). The main purpose of this organisation was to delind the Turkish Cypriot people against EOKA!" The Turkish Resistance Organisation was mainly dependent upon British defence.

Prior to the Zurich and London Agrements, Greece wanted to win international recognition for the enosis at the UN and reneved and continued EOKA violence directed against the British and the Tutkish Cypriot community, but they were not successtul. In the end Grece hat to accept that Turkey was an interested party in the Cyprus dispule. As a result. 11x Greek Cypriots believed that Britain had helped the Turkish Cypriol case. due to preventing the achievement of enosis. ${ }^{19}$

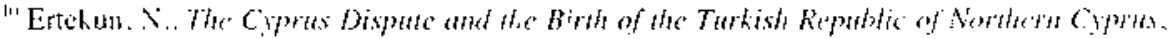

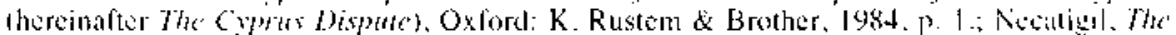
Cymos Qutsisom, p.t

"Dodd. p. 3 .

I. Hid.

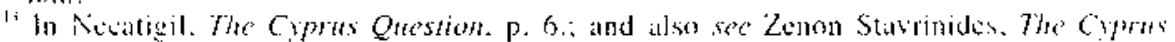

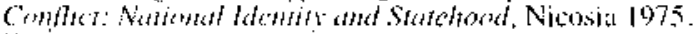

In iveatigil, The Crpitis Question. p. 6.

"Dodd. P. 4

len Midel.

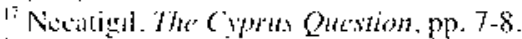

is Dodd. p. 4.

i' Dondd. p. 5
} 
Turning now to the establishment of the Republic of Cyprus, the Constitution of Cyprus was based on two prior international agreements. The Zurich Agreement (1! February 1959), concluded between Turkey and Greece, set out the "Basic Articles" of the Constitution. ${ }^{20}$ It established a bicommunal constitutional framework for Cyprus and recognised the equality of the two communities." The London Agreement was signed by the British Foreign Secretary and the Prime Ministers of Greece and Turkey. It comprised of a Memorandum and a collection of agreements which would facilitate 'the agreed foundation for the final settlement of the problem of Cyprus'. These agreements consisted of the texts of the third agreement, namely "The Treaty of Alliance and the Treaty of Guarantee"?2 that constitutes the 'Basic Structure of the Republic of Cyprus' and declarations made by the representatives of both communities approving the documents "as the agreed foundation for the final settlement of the problem of Cyprus". In addition to the Foreign Ministers of Greece and Turkey and the British Foreign Secretary, the representatives of the Greek Cypriot and Turkish Cypriot communities signed these documents. ${ }^{2 i}$ On 16 August 1960, the British Colony of Cyprus became an independent State whose name was the Republic of Cyprus. After the above referred three multilateral treaties, Cyprus, the British Colony, achieved its independence. In the Treaty of Establishment, it was accepted that the Republic of Cyprus would have sovereignty over the Island, with the exception of two British military bases. In the Treaty of Guarantee, the signatories recognised and guaranteed the independence, territorial integrity and security of the Republic of Cyprus, and "the state of affairs established by the Basic Articles of its Constitution". In the Treaty of Alliance, the parties agreed to resist any attack or aggression directed against the independence or territorial integrity of the Republic of Cyprus. Great Britain was not party to the Treaty of Alliance. $2-4$

The Constitution of Cyprus was carefully drafted and its Basic Articles recognised the equality of the two communities and their obligation to share the attributes of sovereignty. Under this regulation the President of the Republic was a Greek Cypriot and the Vice-President was a Turkish Cypriot. Each community would select its official simultaneously but separately by majority votes of their respective communities. These officials

\footnotetext{
"Leigh. M., "The Cypriot Conmunities and International Law", (Winter 1990) Turkish Review - Quarterly Digest.p. 48 .

?I Dodd, p. 5 .

"Treaty of Alliance between the Kingdom of Greece. the Republic of Turkey, and the Republic of Cyprus. August 16, 1960.397 U.N.T.S. 289. Treaty of Guarantee. August 16, 1960,382 UI.N.T.S. 3.

"Necatigil. Z., M.. "The Cyprus Conflict in International Law", in The Political Social and Economic Derelopment of the Northern Crpros, (ed. C. H. Dodd). Huntingdon: The Enthen Press. 1993. p. 47.; Ertckun. The Cyprus Dispute.pp. 7-8.

${ }^{+}$Leigh, p. 48.; McDonald. R. The Problem of Cypres. London: Published by Brassey's Ior the IISS. $1488 / 89 . \mathrm{pp} .10-16$
} 
were empowered to reto in whole or in part any law relaling fo foreinn affitis, defence or security. ${ }^{55}$ The Council of Ministers, the House of Representaltives. the judiciary, the military and the civil service were divided between the wo conmunities in accordance wilh the agred proportions. Al! legislative power relating to the matters of religion, educition. personal status, municipal institutions and aftairs was regulated separatery the Constitution of Cyprus was very detailed and the resime founded in Cyprus was very balanced.

Accorling to the treatics and it: Constitution the Republic of Cypros was estahlished on 16 August 1960 , and recognised by the international community. On 21 Septemtier 1960, it was admitted to the United Nations. On 13 March 1961. it became an independent member of the British Comnonwealth and took its place in the Council of Europe as the sixteenth member on 24 Mav 1961..$^{27}$ The Republic of Cyprus -the carefully balanced and intermatiomatly recognised regime- lasted over thres years. On 30 November 1963. President Archbishop Makarios proposed thirteen amendments to the 1960 Constitution. Six of them were to Basic Articles whicl were declared immutable by treaty and constiutional provision. The main reason for this was the elimination of the carefully negotiated balance of power between the two communities. ${ }^{28}$ The main charateristics of these amendments were "(i) to have the Greek Cypriot President and the TurkishCypriot Vice-President elected by the Greek Cypriot dominated House of Representalives als a whole (not by the Greek-Cypriol and Turkish-Cypriot members separtately): (ii) to remose their veto powers: (iii) 10 reduce the Turkish-Cypriot component in the sivil and mititary arms of government: (iv) to abolish separate community voting on fiscal, electoral and some other matters: and (f) to unify the municipalities". When adopled these thinteen amendments would shift the balarce of power in favour of the Greak Cypriots."

These thirteen amendments, which were proposed by the Greek Cypriots. were an obvious violation of the Constitution and the treaty obligations approved by the Greek Cypriot community. In particular. Article 182 of the Constilution which governs amendments as a "Basic Nricle" and Article 1 of the Treaty of Guarante were violated by the Greek Cypriot

\footnotetext{
$\because$ Lcigh. pp f(9-50.

Ltevigh, p. 501

? Thid.

"Nidl.

"Dodid, p. 7

:31 Leigh, p. 50.
} 
regime. Thus, these amendments cannot be validly accepted any international recognition."

This movement can be seen as a part of the alleged "Akritas Plan". ${ }^{32}$ It was drawn up in 1963 and was originally published by a local newspaper (Patris, on 21 Aprit 1966). "The main purpose of the plan was to end the new republic. In compliance with this plan, the Greek Cypriot side claimed that the 1960 Constitution was unworkable and had to be amended. As indicated in the plan, the final purpose was cnosis which could have been achieved by means of self-determination ${ }^{\text {it }}$ Moreover. the Greek Cypriot side considered the Turkish Cypriot community as a "minority" in a Greekruled island, with no right of self-determination and this attitude is still prevalent today. As mentioned above, the Greek Cypriot side's attitude was obviously in violation of the treaties and the Zurich and London Agreements. This is because, they created a bi-communal State, not a nation.

The Turkish Cypriots and Turkey rejected the proposed constitutional changes. After the breakdown of the 1960 Constitution by the Greek Cypriot community, the uneasy years (1963-1974) began for the Turkish Cypriots. In December 1963 the intercommunal fighting began. On 21 December 1963 a Turkish couple were killed and after that, a major attack on the Nicosian Turkish Cypriots was launched by the Greek Cypriots. The Turkish Cypriots were generally defenceless since the Turkish police had been disarmed because of a ruse on the part of the Greek Cypriot minister. During the 1963 64 crisis, as a result of Greek Cypriot violence against the Turkish Cypriots particularly in Nicosia and Lamaca - about 20.000 Turkish Cypriots fled from their 103 villages to safer areas. ${ }^{36}$ As a consequence of this violence, the Turkish Cypriots were left as "stateless persons" in their homeland. In order to prevent any further violence, the United Nations Peace-Keeping Force (UNFICYP) was sent to the Island in $1964 .{ }^{37}$ The aim of this paper is not to give detailed information about the Cyprus problem as information concerning the period of the uneasy years can be found in detail in the UN Secretary General's Report ${ }^{39}$, the British journalist H. Scolt Gibbons' book $^{39}$

\footnotetext{
"Leigh, p. 51.

3. The text of the Akritas Plan is available in 2. M. Necatigil. The Cyprus Question and the Turkish Position in htornational Lau'.

${ }^{33}$ Necatigil, The Cyprus Question, p. 26.

w Mid.

"Necatigil. Z., M. "Democratic fnstitutions in Divided Sncieties: The Case of Cyprus". (1992) 1 Revue Des Droits De L'Homme (Human Rights Review) p. 28. Groom. A.. J.. R.. "The Cyprus Negotiations: Taking the Horses to Water". http:/snipe.ukic.ac uk/international/papers.dir/groom 3.html. p. 3.

it Drold, pp. 6-7.; Ertekun. "The Historical Background". pp. 191-192.

${ }^{37}$ Feyzioglu. T.. and Ertekun. N., M.. The Crux of the Cyprus Qwestion, Lefkosa: Meteksan Press. 1987. pp. 10-1 I.

${ }^{3}$ UN Document Number $\$ / 5950$, especially. paras. 7-11, 50, 103.222.
} 
and Professor Pierre Oberling's bock. ${ }^{\text {th }}$ The period of uneasy years was ended by the Turkish intervention in Cyprus in 1974.

\section{The Reasons for the Establishment of the Turkish Republic of Northern Cyprus}

Despite the breakdown of the 1960 Constitution and its unilateral amendment by the Greek Cypriots, the UN Security Council (Resolution 186) recognised the Greek Cypriot government as the legitimate govermment of Cyprus. This recognition and the subsequent recognition by other States exccpt Turkey - of the Greek Cypriot government as the legitimate government of all the Island is resented in Northem Cyprus. As a result of this situation, the Turkish Cypriots have had serious economic and other effects. ${ }^{+1}$ Since 1964 the Greek Cypriot State has claimed to be the sole govemment of the Republic of Cyprus, with power over the Island and its inhabitants. No legal basis can be found in international law for such a claim. ${ }^{+2}$ As indicated above, the legal status of the Greek Cypriol regime wals an obvious violation of the Treaty of Guarantee, the Zurich and London Agreements and the 1960 Constitution. It is not the same government of the Republic of Cyprus which was recognised by the international community in 1960. Moreover, it is not the legitimate successor of that government. Therefore, the Greek Cypriot State had in 1964 and has today no right under international law to claim sovereign rights over the Turkish Cypriot community. "Currently the Greek Cypriot government represents only the Greek Cypriot community. In short, it is not the Republic of Cyprus which was established and governed by the treaties and the 1960 Constitution. ${ }^{4}$

The establishment of a Greek Cypriot State in the South and its recognition as the legitimate goverrment of whole island by the UN and international community together with the fact that the Turkish Cypriot side had respected the sanctity of the treaties and insisted on the implementation of the 1960 Constitution, caused the Turkish Cypriot people to decide to set up their own State.

Under these circumstances, the parallel administrative, judicial and legislative organs for each of the two communities were set up. From 1964

\footnotetext{
${ }^{34}$ Gibboms. H.. S.. Peare Withou Honow, Antata: Ada Publishing House. 1969.

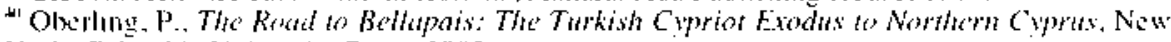
York: Columbia l'niversity Press. 1982.

+ Dexld, p. 8

t? Leigh. p. 5]

4. Hid.

"Necatignl, "The Cyprus Conllict", p. 56.

${ }^{55}$ Necatigil. "The Cyprus Conflict", p. 55
} 
to the present day, the Greek Cypriot government, which has claimed to be the government of the Republic of Cyprus, has not exercised any sovereign rights over the Turkish Cypriol community with regard to the importan incidents of sovereign control reserved to the Republic of Cyprus government in its Constitution." The report of the Secretary-General on the United Nations in Cyprus (S/6228, para. 203, 11 March 1965) proves this fact as follows: "inaccessibility of the areas inhabited entirely by Turkish Cypriots to the Government's law-enforcing authorities and officials. The organs of the State are thus powerless in these areas to administer justice". For instance, no taxes have ever been collected from the Turkish Cypriot people by the Greek Cypriot government (paras. 178-181). The Turkish Cypriot community and the Greek Cypriot community have separately made all decisions relating to their own communities by means of each side's govemmental institutions. ${ }^{17}$

The situation of parallel government and physical separation of the two Cypriot communities continued after the coup (coup d'etat) of 15 July 1974 which was organised by Greece. Its main purpose was to unite the Island with Greece; however it failed due to the Turkish intervention which was made under the Treaty of Guarantee 10 protect the Turkish Cypriots on 20 July $1974 .^{4 *}$ In section 5 of the Geneva Declaration of 30 July 1974, issued jointly on behalf of Greece and Turkey, the United Kingdom recognised the existence of two administrations with the following words: "the existence in practice in the Republic of Cyprus of two altonomous administrations, that of the Greek Cypriot conmunity and that of the Turkish Cypriot community". In contrast to the Greek Cypriot's opinion that "Cypris for the first time had been separated into two largely... ethnic zone"taty the Turkish intervention did not change the equal legal status of the two Cypriot communities which came from the treaties and the 1960 Constitution. The reason for this conclusion was that the Greek Cypriot and Turkish Cypriot peoples had been living as separate and parallel self governing communities since 1964. The origin of the physical separation of the two communities was not the consequence of the Turkish interventionst but was the result of the UNFICYP separating these two communities in 1964.

The practical consequence of the separateness of the two communities in Cyprus, on 13 February 1975, was that the Turkish Federated State of

\footnotetext{
*" Leigh. pp. 51-52.

"Leigh. p. 52 .

th Necutigil. "The Cyprus Conflict", pp. 60-61.: Leigh, p. 52

ty Coufoudakis, V.. "Domestic Politics and the Search for a Solution of the Cyprus Problem". in Cyprus A Regimal Conflict and Is Resolutiom, (ed. Norma Salem). Ottowa: St. Martin's Press. 1992, p. 20.

"Leigh. p. 52

${ }^{5}$ Leigh. p. 52 .
} 
Cyprus (TFSC) (atter the Autonomous Cyprus Turkish Administration) was established with the adoption of its Constitution. This Constilution was in compliance with a federal solution of the Cyprus problem. The aim of the Turkish Cypriots by virtue of the establishment of the TFSC was to create the legal basis for setting up the future independent Federal State of Cypus. On 15 November 1983, the Turkish Cypriot people declared their independence under the name of the Turkish Republic of Notthem Cyprus (TRNC). The decision of the Turkish Cypriot community should be accepted equally with those of the Greek Cypriot community. This is because since 1963 (over 20 years) the Turkish Cypriot people have negotiated in good faith with the Greek Cypriot community in order to achieve a lasting political solution 10 the Cyprus problem. " During the negotiations between, the two Cypriot communities under the auspices of the UN, this lasting political solution, a federation based on two politically equal components, could not be achieved. The main reason for this failure was that the Greek Cypriots did not want to share the power due to the continumg recognition of the Greet Cypriot government by the international comnunity as the legitimate government of the whole island. For this reason and also die to the other reasons mentioned above, the Turkish Cypriots had to declare their independence under the name of the TRNC.

\section{The TRNC as an Independent State}

The Turkish Republic of Northern Cyprus was established as an independent State in the exercise of the right to self determination by the Turkish Cypriot people on 15 November 1983. At this point, the yuestion in relation to the leyal status of the TRNC with regard to the cloments of statehood. laid down by international law, will be briefly assesied hore. In other words. does the TRNC, in fact, possess the criteria for statchood? The basic criteria for statchood reflecling the customary international law rulc is Articic 1 of the Montevideo Convention on the Rights and Duties of State. $(1933)^{57}$. These are: (a) permanent population: (b) a defined territory: (c) at government: and (d) a capacify to enter into relations with other States (independence).

\footnotetext{
"Necaligit. "The Cyprus Conllict", p. 6r.

"Lecigh. p. 52.

Whid.

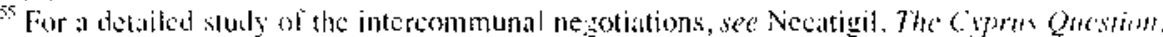

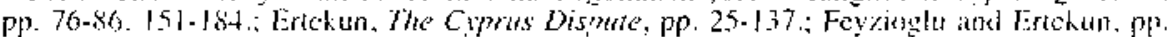
$39-49$.

"Ertckun. "Tho Historical Background". p. 197.

s? Montevideo Comvention on Rights and Cutics of States (1933). 165 L.N.T.S. 19.. U.S.T.S.

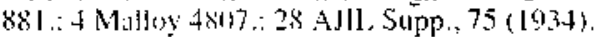


Recognition, as will be seen below, is generatly not accepted as a criterion for statehood. According to the constitutive theory, a State becomes a subject of international law only and exclusively through recognition, in short, recognition creates statehood in international law. In contrast to this theory, according to the declaratory or evidentiary theory, the concept of recognition is not a criterion for statehood. A State exists as a matter of fact. whether it is recognised or not. Recognition is nothing other than a formal acknowledgement of an established situation of fact. ${ }^{5 *}$ In modern international law, almost all international lawyers accept the declaratory theory wive to the fact that it has often been recognised for political reasons."

When the case of the TRNC is assessed in the light of the requirements of statehood the following results are found:

The first criterion for statehood is to have a permanent population. The TRNC has a population of 170.000 (99\% Turks and $1 \%$ others). ${ }^{(1)}$ The size of population is not important in deciding the question of statehood. As a recognised State, Nauru whose population is less than 10.000 proves this fact. San Marino. Tuvalu and the Vatican City are further examples of recognised States with small populations.

The second criterion is to have a defined territory. The territory of the TRNC covers 3.355 square kilometres ${ }^{61}$ and its border of 189 kilometres runs from the tip of Karpas peninsula in the East to Erenkoy in the North West. The boundary of the TRNC was defined in the case of the Green Line in Nicosia in 1964. In this sense, the UN Peace Keeping Force has played a central role. In particular, after 1974, the boundary line began to assume the qualification of an international boundary." To be a State a certain frontier is not necessary. The situation of, Israel is the best example to show that even though its borders are not defined Israel is a recognised and a member State to the UN. ${ }^{3}$ In case law, the cases of Deutsche Continental Gas Gesellschaft $x$. Polish ${ }^{6 t}$ and the North Sea Continental Shelf Cases ${ }^{\text {ti. }}$ also confirm this point.

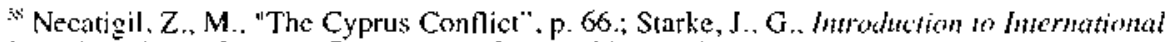
Lan', 9th cdition. London: Butterworths Press, 1984, p. 128.

${ }^{54}$ Ibid.

"The Turkish Republic of Norhern Cyprus, published by the TRNC Prime Ministry Public Relations Department. Lethosa 1995, p.I.

"Ibid.

Groom. p. 4.

th Necatigil. The Cypras Question. p. 314.; Dixon, M., International Law, London: Blackstone Press. 1996. p. $10 \mathrm{H}$.: Shaw, M.. N.. Intemational Law, 2nd edition. Cambridge: Grotius Publications. 1986, p.127; Harris. D.. J., Cases and Materials on International Law, London: Sweet \& Maxwell Press. 1991,pp. 103. 206-208.

(1929-30) AD 5 p. 11.
} 
Relating to the terrilory of the TRNC there are some points which need to be examined. Thit territory of the TRNC is 3.355 square kilomelres which is neirty 35.03 per cent of the whole territory of Cyprus. The Greek Cypriot side argues that the TRNC has no "territory" of its own on the ground that the atea of the TRNC belongs to the territory of the Republic of Cyprus."

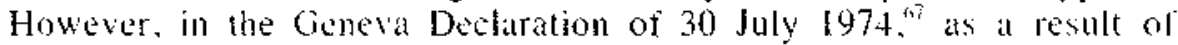
evolutionary developments the existerice of two separate and autonomous administrations -the Greek Cypriot community and the Turkish Cypriot community - was accepted in the teritory of the Republic of Cyprus by the Ministers of Greece. Turkey and the UK. Neither of these administrations existing on the [stand are qualified to claim that they are the alministration of the Republic of Cyprus." Moreover, the Four Guidelines of 12 Februtity $1977^{\text {(n) }}$ agreed upon by Mr. Denktas, President of the Turkish Federated State of Cyprus, and Archbishop Makarios, the leader of the Greek Cypriot community, is an oflicial acknowledgement of the territory under the control of each separate community (Guideline section 2). In order to solve the Cyprus problem, it is generally accepled at present that the solution will be based upon the principle of bi-sonality. ${ }^{7}$

The other contention of the Greek Cypriol side is that the Turkish Cypriot community oceupy the territory which is larger than their proportion of the whole population of the lsland. Eit it should be remembered that most of Northem Cyprus is mountainous and arid. "Besides, the Turkish Cyprots need enough arable land to feed themselves - especially in view of the continuing efforts by the Greek Cypriots to throtte the Turkish Cypriot economy". "

The thind criterion for statehood is to be an effective government. The TRNC has a democratic constitution and all the organs of government. The Constitution of the TRNC sets out a system of separation and of checks and balances between the Legislature, the Executive, and the Judiciary. It consists of 16.3 Arlicles and was approved by 70 per cent of the voting public at a relerendum held on 5 May 1985. The Constitution prohibiss racial discrimination and safeguards the equality of all individuals before the law. It observes the principles of parliamentary democtacy, social justice and the

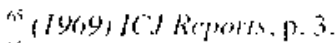

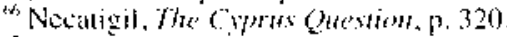

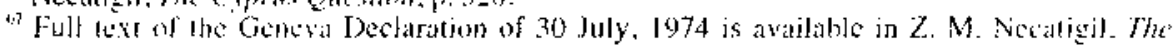
Cypros Question-1p. $+12-414$.

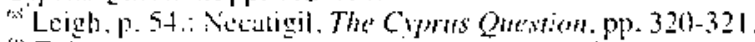

(t) This meeting was betd tuder the allspices of the Secretary General of the Liniled Nations. See (NN Doc. S/ 2323

Nitedicil. The Cypros Questiom, p. 321.

"Oherline. P. Cyprus Yesterday and Tuday. An Updated Version of a lublic Lecture Given at the Universily of Texis al Austin on March 7.1995. p. 13.
} 
rule of law. It also establishes and safeguards secularism. The Constitution stipulates the holding of elections every five years under the general ditection and control of the judicial organs.

The Legislative Power is exercised on behalf of the people of the TRNC by the Assembly of the Republic (Parliament) which has 50 seats.

The executive duties and powers are carried out and exercised by the President of the Republic and the Council of Ministers in compliance with the Constitution and laws.

The judicial powers are exercised on behalf of the people of the TRNC by independent courts. ${ }^{72}$

With regard to an effective government (administration) in Northern Cyprus, the decision of the Court of Appeal in the case of Hesperides and Another v. Acgean Turkish Holiday and Anothes ${ }^{73}$ is very important, although it is related to the laws of the Turkish Federated State of Cyprus. The following statement from this case is evidence of the existence of an effective government in Northern Cyprus: "There is an effective administration in nothern Cyprus, which has made laws governing the day to day lives of the people. According to these laws. the people who have occupied these hotels in Kyrenia are not trespassers. They are not occupying them unlawfully. They are occupying them by virtue of a lease granted to them under the laws or by virtue of requisitions made by the existing administration". ${ }^{74}$

The fourth criterion for statehood with respect to the traditional requirements of statehood is independence (a capacity to enter into relations with other States). In this context, the independence of the TRNC was criticised by international lawyers. The Greek Cypriot side asserts that "invasion" and "continued occupation" by Turkey destroys the independence of this State. In response. the Turkish side insists that the Turkish forces are in Northern Cyprus at the request, and with the consent, of the effective administration of the territory. The reason for the existence of the Turkish forces in Northern Cyprus is to protect the Turkish Cypriots. After a solution is found, they will no longer be settled in Cyprus. ${ }^{75}$ Moreover, governments are free to enter into alliances with other countries for their mutual

\footnotetext{
${ }^{72}$ For further information, see' Necatigil. The Cyprus Questiom, Ch. 13, pp. 296-309.

${ }^{73}$ Hesperides and Another 1 . Acgean Tukish Holiday and Anoher (1977) 3 WLR 656.; (1978) ] All ER 277.

${ }^{74}$ (1978) 1 All ER p. 285

${ }^{75}$ Necatigil. "The Cyprus Conflict". p. 68 ; Necatigil, The Cyprus Question, pp. 326-327.
} 
protection. In the Cyprus situation. Ireaty rights exist, Turkey was invited to come so ats lo protect the independence of Cyprus and to protect the Turkish Cypriots who were in danger. "The TRNC is not the only Stale which is hosting another States' troops in the world. Under defence aureements or oher type of arrangements, a number of States allow forcign forces to station in their territories.?

As regards to the Turkish intervention in 1974 it should be remembered that it was made in accordance with the 1960 treaties. In particular, Article 4 of the Treaty of Guarante gave the right to each guarantor power to intervene in Cyprus in order to mainlain the status quo set otl between the Greek Cypriol and the Turkish Cypriot communities on the Island in 1960." "Turkey exercised its rights in 1974 by invading the island following a coup d'etat orsanised by the Greek military dictatorship against Cyprus levitimate government" "In this sense, there is one important point which is ignored by the international community and international lawyers, which is, that it is common opinion that the TRNC was created as at result of the use of illegal force. thus the TRNC cannot te seen as a State. ${ }^{\mathrm{xt}}$ One of the most fundamental principles of intemational law is the prohibition of the threat or use of force against the territorial integrify or political independence of any State in international relations (Article 2 (4) of the UN Charter). For this reasolz, a State created as a result of illegal use of force is not in accordance with the principles of international law. Such a State depends directly apon this illegal intervention. In the situation of the Turkish intervention of 1974 these principles of international law cannot be applied to the TRNC for the following reatsons: Firstly, the 1974 Turkish military intervention was not illegal. It was made in compliance with the principles of the Treaty of Guarantee. Under this treaty, Turkey lad a right and obligation to intervene and to protect the Turkish Cypriots and the Republic of Cyprus. Secondly, the TRNC was established on 15 November 1983 falmost nine years after the Turkish intervention). This situation proves that the TRNC was not the result of the Turkish intervention of 1974. The TRNC was the last step of the process of political and administrative evolution which began in 1963 . Finally, relating to the territory of the Republic of Cyprus, the TRNC did not occupy the territory of the Republic of Cyprus as this had already been destroyed by the Greck Cypriots in 1963. Two autonomous and exclusive administrations have replaced the government of the Republic. In the

\footnotetext{
"Denktas. R. Recognition - A Right. Speech Delivered by If. E. President Ratul Dinhtils at Eastem Mediterramean University. (Gomagusa. 21 November 1900. p. 2.

${ }^{73}$ Necatiglt, "The Cyprus Contict", p. 68.

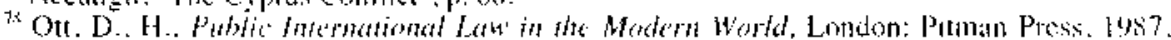
p). $57-58$

"Ihid.

Dixon. p. 164: Harris. pp. 113.847.
} 
Geneva Declaration of 30 July 1974 , this fact was acknowledged by the three guarantor powers. ${ }^{81}$

The 1974 Turkish intervention can also be assessed as a humanitarian intervention ${ }^{82}$ in international law. The concept of humanitarian intervention is a grey area between self-defence (Article 51 of the UN Charter) and illegal use of force (Article 2 (4) of the UN Charter). ${ }^{4.3}$ In the case of an immediate and extensive threat to fundamental human rights, especially, a threat of widespread loss of life, the basis of humanitarian intervention may be claimed. ${ }^{x_{4}}$ When the United States invaded the Dominican Republic in 1965, Grenada in 1983 and Panama in $1989^{85}$ it relied upon this legal basis. Similarly, in the Bangladesh case, the Indian intervention was based upon the violation of human rights by Pakistan in East Bengal (Bangladesh). When the history of the two communities, the Greek coup of July of 1974 and the human rights violation made by the Greek Cyptiots ${ }^{k \overline{7}}$ are examined, it can be clearly seen that the 1974 Turkish intervention is nothing other than a humanitarian intervention.

\footnotetext{
81 Necatigil, The Cyprus Question. pp. 322-326.; Leigh. pp. 57-59.

" Humanitarian intervention "refers to the use of armed force by one state against another for the purpose of saving the lives or property of the intervenor's citizens or others in the second state or rescuing them from an imminent threat of grave injury" (Ott, p. 313).

Ott, p. 313.

"Necatigil. "The Cyprus Conllict", p. 69.

"Harris, pp. 845-847; Ott, pp. 313-314.

"Frank. T., M.. and Rodley, N., S.. "After Bangladesh: The Law of Humanitarian Intervention by Military Forec", 11973) 67 AJIL p. 275.: Harris. p. 847.; Crawford. J.. The Creation of States in International Law, Oxford: 1979, Pp. 170-173.

${ }^{3}$ The World Press proves how the Turkish Cypriots' human rights were violated by the Greck Cypriots. Examples: "Bands of lormer EOKA members and other irregulars, in groups of about a hundred usuatly led by police took part in the operation; 700 hostages. including women and children. were seized in the northern suburbs, and Turks were murdered in their homes". (Nancy Crawshaw, in "The World Today", BBC. August, 1964,; "In a Greek raid on a small Turkish village near Limasol. 36 people out of a population of 200 were kilted. The Greeks said that they had given orders to kill the inhabitants of the Turkish villages before the Tutkish forecs arrived". (The Washington Post, 23 July 1974): "Members of the Greek Cypriot National Guard were mercilessly murdering all the civilian men. women, and children of the Turkish Cypriot villages and towns". (Reported by Kurt Lariken Correspondent of the Die Welt Newspaper, 22 August. 1974).: "Corpses of 88 Turkish Cypriots have been discovered on a rubbish heap. in Nicosia. The people had been gunned down by Greek Cypriots and Greeks and before their murder they had becn tied up with wire. The heads of some of the corpses had been severed from the bodies" ${ }^{n}$ (Reported by CBS Television. 22 August. 1974).; "The human mind cannot comprehend the butchery of the Grecks. In the villages around the Famagusta region the Greek National Guard have displayed unsurpassed examples of savagery. Entering Turkish homes. they ruthlessly rained bullets on women and children. They eut the throats of many Turks". (Interview given by German Tourist. Mrs. Ingried Habel. Broadcast by the Voice of Germany on $30 \mathrm{July}$. 1974).; and also see "Report on Mass - Graves at Alos and Maratha". The Guardian, 21 August 1974 "Bloodstained Arclibishop and his Savage Dogss of War". The Daily Sketch, 10 August 1964.; "The UN Must Act". The Washington Post, 22 May 1964.; The London Times, 22 July 1974.; Homam Rights in Cypras. A Publication of the Turkish Cyprion Human Rights Committee. Nicosia (Letkosa): Tezel Otiset Press, 1979.; Ball. G., The Past Has Another Pantem, (Memories. Nonon and Co. 1982), pp. 34 J.347.
} 
With regard to the independence of the TRNC one more point which should be noted is that the Turkish forces do not lake part in the administration of the TRNC. On the other hand, there are also the Greek forces in Southern Cyprus. ${ }^{*}$ This issue has never been criticised in terms of the statehood and recognition of the Greek Cypriot government by the international communily and international lawyers. ${ }^{\text {sy }}$ As indicated above, the TRNC was establisted as a result of evolutionary developments. Since 1963. the Turkish Cypriol people have exercised their own govermmental authority and control over the territory of the TRNC.

In short. the TRNC has the criteria of statehood. In addition to the traditionial requirements of statehood ir international law, some other criteria such as permanence. willingness and ability to observe international law, a certain degree of civilisation, legal order and sovereignty can be observed in the TRNC's case. Although the TRNC possesses the criteria of statehood, the UN and the international community (except Turkey) have not recognised the TRNC as an independent State. The UN Security Council Resolution of 54 ! (1983) of 18 November 1983 concluded that the declaration of the TRNC was legally invalid and called upon all States not to recognise the TRNC. The assessment of the UN Security Council Resolution will be made below.

\section{The TRNC and Recognition}

Before examining the legal status of the TRNC as regard to its recognition, some important facts which are arguable in international law need to be explained. These are: "The Treaty of Guarantee and International Law". "The Legality of the Turkish Intervention" and "The Right of the Turkish Cypriot People to Self-Determination".

\subsection{The Treaty of Guarantee and International Law}

The Treaty of Guarantee ${ }^{(x)}$ is one of the treaties establishing the Republic of Cyprus. It was signed by the UK. Greece. Turkey and the

\footnotetext{
in According 10 the Foreign Aflairs Committe of the House of Commons Report of 7 May 1987 on Cyprus. 'UN estimates, conlirmed by British sources, suggest that there remain about 2.500 regular Greck troops (mainly officers and NCOs) in support of a Cypriot National Getard of between 11.000 and 12.000 men. In addition. there are a sutwetantial mumber of Greck Cypriot reservists. estimated at about 50.000 by the UN and about 60.000 by the Institute of Siatedic Studies'. (para. 58), the level of Turkish troops was around 27.5ion in December 1986 and that the number of the Turkish Cypriot security loree is gencrally regarded to be about 4.300 (para. 1.37).

${ }^{*}$ Necatigil. "The Cyprus Conltict". p. 69; Necutigil, The Cyprus Question. Pp. 327-328.

" ${ }_{1}$ The full text of this treaty is available in N. Ertekun, The Cyprus Dispute.
} 
Republic of Cyprus. It consists of four substantive Articles. According to Article I, the Republic of Cyprus accepted the obligation to maintain 'its independence, territorial integrity and security, as well as respect for its Constitution'. This Article also declared another obligation to the Republic of Cyprus, which is not to participate in any political or economic union with any State. In Article II. Greece, Turkey and the UK recognised and guaranteed 'the independence, territorial integrity and security of the Republic of Cyprus, and also the State of affairs established by the Basic Articles of its Constitution'. Under Article III, the Republic of Cyprus, Greece and Turkey undertook the obligation 'to respect the integrity of the areas retained under United Kingdom sovereignty at the time of the establishment of the Republic of Cyprus and guarantee the use and enjoyment by the United Kingdom'. Lastly, according to Article IV, Greece, Turkey and the UK were accepted as guarantor powers in the case of a breach of the provisions of the treaty.

From the point of the principles of international law, Articles 2 (4) and 103 of the UN Charter reflect an arguable position with the Treaty of Guarantee. Thus, the text of the Article needs to be examined. It states:

"In the event of a breach of the provisions of the present Treaty, Greece. Turkey and the United Kingdom undertake to consult together with respect to the representations or measures necessary to ensure observance of those provisions.

In so far as common or concerted action may not prove possible, each of the three guaranteeing Powers reserves the right to take action with the sole aim of re-establishing the state of affairs created by the present Treaty".

When this Article is interpreted as authorising the use of force, an argument relating to the Treaty of Guarantee arises, whereupon it is against to the principles and purposes of the UN Charter (especially Articles 2 (4) and 103 ) and to the principles of international law."

Firstly, as regard to the peremptory norms (jus cogens) of international law, the legality of the Treaty of Guarantee is arguable. As known from Article 53 of the Vienna Convention on the Law of Treaties (1969) 'a treaty is void, if, at the time of its conclusion, it conflicts with a peremptory norm of general international law. ...a peremptory norm of general international law is a norm accepted and recognised by the international community of States as a whole as a norm from which no derogation is permitted and

${ }^{91}$ Necatigil, The Cyprus Question. p. 116. 
which can be modified only by a subsequent norm of general international law having the same character". On the other hand. Article 4 of the Lim of Treaties states that 'the Convention applies only to treaties which are concluded by States after the entry inlo force of the present Convention with regard to such States'. This means that, the Vienna Convention hats no retroactive application. For this reason, it cantot apply to the Treaty of Guarantee, which was signed in 1960 . However, it is accepted that the Viemna Convention on the Law of Treaties reflects the existing rules (customary rules of international law). ${ }^{22}$ Thus, in this paper. the application of the Latw of Treaties is assumed to the Treaty of Guarantee.

As indicated above, if a treaty is not in compliance with a peremptory norm of international law it is void. However. what the peremplory norms of international law are, is not clear. Some suggested examples are: a treaty providing an unlawful use of force contrary to the provisions of the Charter: a trealy providing slave trade, piracy or genocide. ${ }^{93}$ In this sense. the of force is not against the peremptory norms of international law. Since the Treaty of Guarantee does not consist of unlawiul use of force, it cannot be said to be against the international law practice, and even to the peremptory norm of international law'

Morcover, in the case of Cypra; reasons for concluding of the Treaty of Guarantee and the circunstances under which it was signed should be examined. There is no peremptory norm in international law prohibiting intervention. according to a treaty to which the subject State is a party." The sovereignty of the Republic of Cyprus, in this context, is restricted, because of the treaties establishing the State. The status of the British Sovereign Base areas can be an anolher example to this restriction.

Sccondly, as regard to Article 2 (4) of the UN Charter, the Treatly of Guatrantee creates a number of difficult issues. It states: "All Members shatl refrain in their international relations from the threat or use of force against the territorial integrity or political independence of any state, or in any oher manner inconsistent with the Purposes of the United Nations".

The Greek Cypriot side argued that under Article 2 (4) of the Charter, Turkey has no right to intervene in Cyprus according to the Treaty of Guarantee. This is because, the UNN Charter prohibits use of force. In

"Irid. pp. $116-117$.

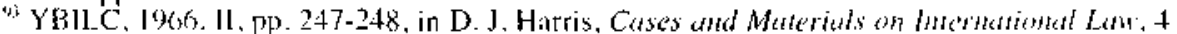
th odn.. B_ondon: Suect \& Maxwell Press, 195,1, p. 791.

in Necatigil. 7he Cypists Question, p. 118

"Ehrlich. T'. Inemutomat Crises and the Rule of Law Cyprus 1958-1967. Oxlord, 1974, pp. 76.77 . 
contrast, the Turkish side urged that military intervention cannot be considered to be against the territorial integrity or political independence of Cyprus under Article IV of the Treaty of Guarantee, because the aim of the treaty as indicated in Articte I was 'to ensure the maintenance of its (the Republic of Cyprus) independence, territorial integrity and security'. ${ }^{\prime / 6}$

Under these circumstances, the issue of whether a military intervention can be in compliance with the Purposes of the United Nations should be discussed. Reisman, ${ }^{97}$ suggests that the use of force should not automatically lead to accusations and that any action -coercive or otherwise- must be assessed according to its positive and negative effects on an established order. And he also suggests that "in the construction of Article 2 (4), attention must always be given to the spirit of the Charter and not simply to the letter of a particular provision" ${ }^{14}$ "When the history of Cyprus and the situation after 1964 are taken into account, the importance of this opinion is clearly realised with regard to the necessity of the use of force in certain situations.

Moreover, while the Treaty of Guarantee is assessed as regard to Article 2 (4) of the UN Charter, at the same time, Articles 51 and 52 (1) of the Charter should also be considered. Article 51 regulates the conditions of self-defence. Article 52 (1) acknowledges that the existence of regional arrangements or agencies for dealing with such matters relating to the maintenance of international peace and security as are appropriate for regional action'. The Charter does not preclude such arrangements or agencies and their activities as long as they are consistent with the Purposes and Principles of the UN. Under these regulations, the guarantor powers, in the Treaty of Guarantee, can act as a 'regional arrangement'. In the case of Cyprus, the Treaty of Guarantee provides a regional arrangement which consists of the use of force in order to achieve its purposes whilst being consistent with the Purposes and Principles of the UN."(t)

Lastly, in this context, Article 103 of the UN Charter will be examined relating to the Treaty of Guarantee. The Greek side frequently argued that under Article 103 of the UN Charter, Article IV of the Treaty of Guarantee was void. Article 103 of the Charter states that: "in the event of a conflict between the obligations of the Members of the United Nations under the

\footnotetext{
Th Necatigit. The Cyprus Question. p. 126.

${ }^{47}$ Reisman, M.. N.. "Coercion and Self-Determination: Construing Charter Article $2(4)$ ". (1984) 78 AJIL p. 642

45 Ibid. p. 643: For opposite opinion. see Schachter. O.. "The Legality of Pro-Democratic Invasion", (1984) 78 AJIL pp. 645-650.

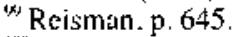

${ }^{r(x)}$ Necatigil. The Cypris Question, pp. 126-127.
} 
present Charter and their obligations under any other international agreement, their obligations under the present Charter shall prevail". However, as mentioned above, the Republic of Cyprus became a member of the UN under the conditions of the reaties establishing this State. The Treaty of Guarantee was one of these agreements. Until now, the UN Security Council and the General Assembly have never declared that the Treaty of Guarantee was void. Moreover, the Security Council in is resolutions emphasised the permanent validity of the Treaty of Guirintes. For example, resolution 353 of 20 July 1974 indicated this fact as follows: "the necessity to restore the constitutional structure of the Republic of" Cyprus established and guaranteed by international agreements". Finally, one more point relating to Article 103 of the UN Charter which should be noted is that even if the provisions of a treaty are in conflict with the Charter, Article 103 of the Charter does not invalidate it. From the interpretation of Article 103, the result that that Treaty being void could hardly be possible. Under the principles of the Charter, the treaty continues to be in force. In this sense, the questions of priority becomes important in intemational law.

\subsection{The Legality of the Turkish Intervention}

On 15 July 1974 the Greek Coup which was planned and directed from Athens and executed by Greeks officers of the National Guard ${ }^{102}$ on the Island took place. ${ }^{103}$ The ajm of the coup was to overthrow Archbishop Makarios and then set up a new government which would unite Cyprus with Greece. ${ }^{\text {i.1. }}$

On 20 July 1974, Turkey invaced Cyprus in accordance with the principles of the Treaty of Guarantee (Article IV of this Treaty)." The aim of the Turkish intervention was to put an end to a take-over of Cyprus by Greece, to protect the Turkish Cyptiot community ${ }^{106}$ and to re-establish the state of affairs created by the agreemerts. ${ }^{107}$ Evriviades ${ }^{106}$ assesses the Greek Coup and the Turkish intervention - within the meaning of Article IIl of the

\footnotetext{
${ }^{1401}$ Hid. pp. 127-129.

112? The Nitionill Guard was set up by Law No. 20 of 1964 of the Greek Cypriol House of Representatives.

${ }^{11 ! !}$ Polyviou. P.. G. Cyprus Conflict and Negotiation 1960-1980. London: Ductiworth Press, 1980.0 .156

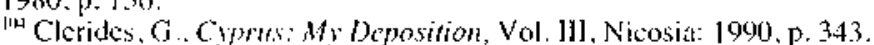

160 Ott. . . 58

"kn Necatigil. The Cipros Questirm, p. 94

"Tamkoc, M.. The Tatish Cyprot State, London: K. Rusten \& Brother, 198s. p. 105.: After the 1974 Turkish intervention, this aim was not found possible. For the reasonts, see Necatigil. The Cypras Qmestion.p. 132.

Kow Eviviades, M.. "The Legal Dimensions of the Cyprus Conllict", (1475) 10 Texas International Law Journal p. 227.
} 
Agreement for Application of the Treaty of Alliance - as follows: "... in 1974 the Cyprus independence and territorial integrity were being actively threatened, and the July 15 coup was a manifestation of such threat... Turkey correctly regarded the coup as tantamount to the de facto enosis and the Greek involvement as a breach of the sine qua non of the 1960 agreements, namely the prohibition of enosis (and partition) as embodied in Article ILI of the Treaty of Guarantee... the coup constituted an 'indirect attack'. As such it was also a violation of both the Treaties of Alliance and Guarantee". .(k)

As indicated above, the legal base for the Turkish intervention was the Treaty of Guarantee. The position of this Treaty in international law was examined earlier, but one point needs to be discussed in detail. The Greek Cypriot side argued that under the Treaty of Guarantee, the right of military intervention to the guarantor powers was not possible. It authorised merely peaceful representation and intercession." However, Article IV of the Treaty states a 'right to take action'. Of course, the word "action" does not qualify "military", but in this Treaty, Article IV (1) stipulates for consultation 'with respect to the representations or measures necessary to ensure observance of those provisions'. In this paragraph, the word 'measures' can consist of use of force as well as intercession. Moreover, Article IV (2) of the Treaty makes the Turkish position stronger. This is because, it gives a 'right to take action' to the guaranteeing powers. If merely unilateral intercession had been enough, there would not have been any reason to put the second paragraph of this Article into the Treaty. ${ }^{\prime \prime}$

As is well known from Article 31 (1) of the Vienna Convention on the Law of Treaties (1969), a treaty should "be interpreted in good faith in accordance with the ordinary meaning to be given to the terms of the treaty in their context and in the light of its object and purpose". When the aim of the Treaty of Guarantee (to forbid any political or economic union of Cyprus within any State) and the history of Cyprus, since 1963, were taken into account, it is understood that the most effective guarantee could be nothing other than military intervention. 'I2 Moreover, before the 1974 Turkish intervention, the Turkish and British governments discussed the position of Cyprus after the Greek Coup in London on 17 and 18 July. The Greek government did not attend, although she was invited. This fact proves that Turkey did not invade Cyprus without the knowledge of other guarantor

\footnotetext{
I(x) Evriviades, p. 262.

"Wippman. D. "International Law and Ethnic Conflict on Cyprus", (1996) 3I Texas Intemational Law Journal pp. 153-I 56.; Necatigil. The Cyprus Question, p. 129.

III Necatigil. The Cyprus Question. pp. 130-131.

"1". Ibid. p. 131.
} 
powers. All the procedural and peaceful requirements were fultilled by Turkey." ";

In addition to these facts, the 1974 Turkish intervention can be accepled as a humanitarian intervention. The Turkish intervention also protected the Greek Cypriots' human rights as well as Turkish Cypriots' human rights. Oberling ${ }^{\text {it }}$ verifies this point in the following: "In any catse, the Turkish intervention was perfectly legal, according to the Treaty of Guaramtec of 1960. ... The Turkish intervention caused the collapse of the hated military dictatorship in Greece and of the brutal Sampson regime in Cyprus. Ironically, it also saved the lives of many Greek Cypriots and preserved the independence of the Greek Cypriot State. Finally, it ushered in a period of peace on the island which has lasted to this day".

In conclusion, we can say that the Turkish intervention in Cyprus in 1974, under Article IV of the Trealy of Guarantee, was in accotance with the spirit of Article 2 (4) and 51 of the UN Charter and therefore was a legal act."'s

\subsection{The Right of the Turkish Cypriot People to Self-Determination}

The principle of self-determination has two different meanings: "internal" and "external" seif determination. Internal self-determination means 'the sovereign equality of existing states, and in particulat the right of a state to choose its own form of govenment ${ }^{1 / 6}$ On the other hand. external self-determination means 'the right of a people to decide its own future." Similarly, Akehurst defines self-determination as "the right of selfdetermination is the right of a people living in a territory to determine the political and legal status of that teritory, for example, by setting up a state of their own or by choosing to become part of another state" IIx It can be understood from these definitions that the concept of self-determination of peoples is a legal right and can be accepted as a jus cogens norm of intemational law. The reason for this is that the right of peoples to self-

\footnotetext{
"Mid. p. 130.

"H Oterling. P.. Cyprus Yesterday and Today. an Updated Version of a Public Lecture Given at the Liniversity of Texas at Austim on March 7. 1995. pp. 9-10.

t15 Tamkox. p. ji17.

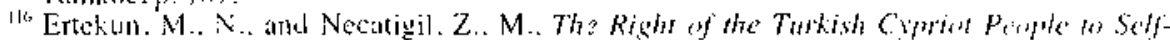
Detorninatiom, Letkosa. 1996. p. 5.

117 lbid.

IIs Akehurst. M.. A Modern horadiction to Leternational Lan', 6th edition. London: Athen and Lnwin Press. 1987. p. 290.

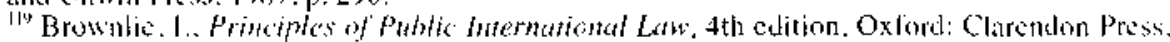
$1990,13.513$.
} 
determination has a vital importance with regard to the human rights norms in international láw. ${ }^{\text {(2) }}$

There is no doubt about the importance of the right to selfdetermination, but the content of this right is less clear. The content of selfdetermination will not be discussed in this paper. However, in order to understand the right of the Turkish Cypriot people to self-determination. international instruments relating to the right to self-determination need to be indicated.

One of the purposes of the UN, as indicated in Article 1 (2) of the UN Charter, is 'to develop friendly relations among nations based on respect for the principles of equal rights and self-determination of peoples, and to take other appropriate measures to strengthen universal peace'. Article 55 of the UN Charter again refers to self-determination dealing with economic, and social development and respect for human rights. The International Covenant on Civil and Political Rights and the International Covenant on Economic, Social and Cultural Rights, which were accepted by the General Assembly of the UN on 16 December 1966. consist of similar Articles with the UN Charter.

The Declaration of Principles of International Law Concerning Friendly Relations and Co-operation Among States in Accordance with the Charter of the United Nations (hereafter Declaration of Friendly Relations) adopted by the General Assembly of the UN on 24 October 1970 regulates the principle of equal rights and the right to self-determination of peoples. The Helsinki Final Act of 1975 (the eight principle) deals with the same principle and also indicates respect for the territorial integrity of States.

While considering the principle of self-deternination the other principle -territorial integrity of States - should be respected. However, this principle is dependent upon the condition whereby such a State has to be 'possessed of a government, representing the whole people belonging to the territory without distinction as to race, creed or colour'. This condition is clearly indicated in paragraph 7 of the Declaration of Friendly Relations. The base for this condition is that the legitimacy of govemment has to come from the consent of the governed. ${ }^{121}$

Taking into consideration the situation of Cyprus, the establishment of the Republic of Cyprus was the exercise of self-determination of the two

\footnotetext{
13) Mullerson. R., International Law Rights and Politics Developments in Eastem Europe and the CIS, London and New York: Routledge and LSE Press, 1994, p. 61.

I:I Necatigil, "The Cyprus Conflict", p. 63.; Ertekun and Necatigil. p. 10.
} 
comnunities -the Greek Cypriol community and the Turkish Cypriot communily'-.'- This fact was described by British Colonial Secretary, Mr. Lennox-Boyd in the following: "It will be the purpose of Her Majesty's Government to ensure that any exercise of self-determination should be effected in such a manner that the Turkish-Cypriot community, no less than the Greek Cypriot community, shall, in the special circumstances of Cyprus, be given lieedom to decide for themselves their future status".

As indicated earfier, the Reputhic of Cyprus was destroyed by the Greek Cypriots after only three years of its establishment. The Basic Articles of the 1960 Constitution were changed. The Turkish members of the Government of the Republic of Cyprus were forced to leave their olfices. Alter 1963-1964, the Republic of Cyprus was replaced by two governments. Since that time, the Greek Cypriol government has not exercised any sovereign tights over the Turkish Cypriot commanity. In this sense, the establishment of a new State by the Turkish Cypriots cannot be in conflict with the principle of respecting the te ritorial integrity of States contained in paragraph 7 of the Declaration of Friendly Relations on the ground that the Greek Cypriot government does not represent the Turkish Cypriot community and does not have the consent of the Turkish Cypriots. Until 1975, the Turkish Cypriots were zoverned by their own atutonomous administration. On 13 February 1975, the Turkish Federated State of Cyprus (TFSC) was established. Finally, on 15 November 1983 the TRNC was set up by the unamimous vote of the Legislative Assembly of the TFSC. It was the result of political and administrative evolution and also the exercise of the right to self-determination contained in the UN Charter, the 1970 Declaration of Friendly Relations and the 1975 Helsinki Final Act. ${ }^{12-}$

In addition to these facts, two more points should be examined in the case of Cyprus. Firstly, the Greek Cypriot government argues that the Turkish Cypriots are not a 'people', they are a 'minority', thus they are not entitled to exercise the right to self-determination. ${ }^{125}$ This argument does not reflect the reality of the situation (the reasons for this were explained above) and the UN resolutions refer to the equality of the two commenties in order to achieve a settlement in the Cyprus problem. The Security Council Resolution 367 of 12 March 1975 and resolution 649 of 12 March 1990 atre just two examples proving that the T'urkish Cypriots are not a 'minority' in Cyprts. ${ }^{12}$ "Without accepting the TRNC and the right to self-detcrmination

\footnotetext{
122 Necatidil, "The Cyprus Confict", p. 63.: Nesatigil. The Cyprus Quesrion, p. 222.

W Statemient in the House of Comnons, 19 De:ember 1956

12+ Leigh. pp. 50-53.: Necatigil. "The Cyprus Contlict", p. 64.: Ertekun and Necatigil. p. 27.

'ts Necitigit. The Cymus Question. p. 221.

${ }^{236}$ Necatigil. "The Cyprus Conflict", pp. 64-65
} 
for the Turkish Cypriots, how can a federation - which is the only way to achieve a final settlement - be formed? ${ }^{127}$

Secondly, the argument that the right to self-determination cannot be applied any more because the principle only applies to peoples under colonial rule. The resolutions of the General Assembly relating to the Palestinians and the inhabitants of South Africa ${ }^{12 x}$ along with the most recent events in Eastern Europe and the dissolution of the Soviet Union have proved that the right to self-determination does not only apply to peoples under colonial rule and also that "it is an ongoing right of peoples". !-9 Moreover, when the recent history of Cyprus is examined, it can be seen that the position of the Turkish Cypriots between 1964 and 1974 was not different from the position of the Palestinians. Thus, recognising the Greek Cypriot government as a legitimate government of Cyprus and denying the Turkish Cypriots' the right to self-determination are violations of international law obligations. ${ }^{130}$

\subsection{The Assessment of the Recognition of the TRNC}

Even though the TRNC meets the requirements of statehood with regard to international law it has still not been recognised by the international community (except Turkey). The most important reason for the act of recognition is that it is considered as a political act of States. States prefer not to recognise a new State if it is not in their interest to do so. When the TRNC was established, only Turkey recognised this State. Pakistan and Bangladesh also wanted to recognise the TRNC, but they were persuaded by the US Government not to recognise this new entity. If these two States had recognised the TRNC, the US aid to these countries would have been cut off. $^{131}$

Furthermore, the UN Organisation did not recognise the TRNC as an independent State. It, in this regard, always follows new developments far from the realities of the world. For example, China for thirty years, East Germany for twenty-five years and Bangladesh for four years were not recognised. In the case of Cyprus, the UN and international community has continued to recognise the Greek Cypriot government as the legitimate government of Cyprus. In fact, The Republic of Cyprus has not existed since

\footnotetext{
${ }^{127}$ Oberling, p. 14.

${ }^{128}$ Akehurst, p. 296; Tankoc, p. 136.

${ }^{13 y}$ Multerson, p. 91 .

${ }^{130}$ Tamkoc, p. 136.

${ }^{131}$ Necatigil, The Cyprus Question, p. 329.
} 
December 1963. The Turkish Cypriots and the TRNC have been deliberately ignored.

The UN Security Council Resolution 541 (1983) of 18 November 1983 was taken atfer the proclamatior of the TRNC. The Security Council considered that the Declaration of Independence was "incompatible with the 1960 Treaty concerning the establisbment of the Republic of Cyprus and the 1960 Treaty of Guarantee". deplored "the declaration of the Turkish Cypriot authoritjes of the purported secession of part of the Republic of Cyprus", and concluded that the Declaration was "legally invalid and calls for its withdrawal" and called upon "all states not to recognise any Cypriot state other than the Republic of Cyprus".

This resolution can be strongly criricised for the following reasons:

Firstly, the Declaration was found to be incompatible with the 1960 Treaty of Estatishment and the Treaty of Guarantee. As is known. the Republic of Cyprus was created as at result of the three treaties. Under these treaties, it is obvious that the establishment of the TRNC as an independent State is nol consistent with that structure. However, when the resolution was taken. the Bassic Structure and the 1960 Constitution had not been in operation for 20 years, (since 1963-64). This was because, the Greck Cypriot community had excluded the Turkish Cypriot community from the administration. This does not mean that the 1960 Treaty of Establishment and the Treaty of Guarantee were no longer in force in 1983. While the Security Council indicated the importance of these Treaties, in the case of the establishment of the TRNC, it has not taken the same allitude with respect to the conduct of the Greek Cypriot community. The Security Council should have shown the same importance in assessing the compatibility of the Greek Cypriof community with these treaties, In this respect, the Security Council had failed. Without having lound that the Greek Cypriot community had been "incompatible with the 1960 Structure of Cyprus", it should not have found that the Declaration of the TRNC was "incompatible" with the Treaties. 133

Secondly, the Security Council accepted that the establishment of the TRNC was "legally invalid". This assessment creates a question which is, according to what faw, is this legality to be determined? Possible candiclates

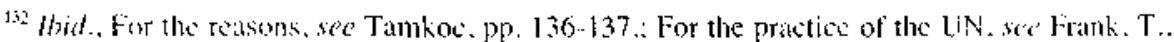
M.. "Of Gnats and Cimmels: Is There a Double Standard at the United Nations"". (1984) 78 AJII p. 811 .

${ }_{133}$ Opinion of Mr. E, Latuterpacht. CBE. OC on the Status of the two communitios ir Cyprus. It has been lifed its a $\mathrm{L} f \mathrm{~N}$ document, bearing reference: $\mathrm{A} / 44 / 968, \mathrm{~S} / 21463$ (1900), (paras. $37-$ 44).; Necatigll, "The Cyprus Conflict", p.7I.
} 
are the constitutional law of Cyprus and international law. Without taking into account the legal validity of the conduct of the Greek Cypriot community, the legal validity of the conduct of the Turkish Cypriot community cannot be assessed. Both communities should be treated with the principle of equality. Being a numerical majority in Cyprus does not give a right to the Greek Cypriots to reject the obligations under the 1960 Constitution and it cannot create inequality of obligation. The 1960 Structure of Cyprus consists of regulations relating to the political act of distributing power and positions in the administration. ${ }^{134}$ In short, the legal status of the TRNC should not be seen as an illegal entity in international law, since the Republic of Cyprus had already been destroyed by the Greek Cypriots. The establishment of the TRNC was the natural result of this destruction.

Thirdly, while the UN Security Council considered that the establishment of the TRNC was illegal and invalid and also called upon all States not to recognise the TRNC. it was acting in a judicial capacity. Under the regulations of the UN, the Security Council cannot act as a judicial body. The International Court of Justice is the judicial organ of the UN. For these reasons, the Security Council should not have determined whether the establishment of the TRNC was legally valid or not. ${ }^{135}$

In addition to the UN Security Council resolution, another factor preventing the recognition of the TRNC has been the intercommunal negotiations. These negotiations still continue although many States suppose that the recognition of the TRNC could badly affect these intercommunal negotiations.

On the other hand, it should also be noted that the view of the UN organs considering the recognition of the TRNC is not in compliance with each other. The best example of proving this fact is that the UN Industrial Development Organisation's (UNIDO) trade section has accepted the TRNC as an "official member" of the association. The trade section's guide book mentions "the TRNC as well as Turkey as a member" In addition to Turkey's recognition, being a member of an international organisation such as UNIDO can be seen as a first step towards legal recognition of the TRNC. ${ }^{137}$

\footnotetext{
1.4. The opinion of Lauterpacht, paras. 45-47.

${ }^{1.15}$ The opinion of Lauterpacht, paras. 51-52.; Necatigii, "The Cyprus Conflict", pp. 71-72.

${ }_{136}^{13}$ Necatigil. The Cyprus Question. pp. 329-330.

1.37 "Legal Recognition for TRNC". The Turkish Daily News (12 July 1997).
} 


\section{The TRNC and the European Court of Human Rights}

As a natural result of the UN Security Council Resolution, the ECHR. in its judgements relating to the Nortiern Cyprus, did not accept the TRNC as an independent State. The case of Loizidou r. Turkey ${ }^{\text {ik }}$ clearly reflects this attittode. In this instance, the applicant, Mrs. Loizidou, complained that her arrest. detention by the Turkish Cypriot administration and the refusal of access to her property, situated in Northern Cyprus were a violation of the European Convention of Human Rights (para. 26). Article 159 (1) (b) of the TRNC Constitution was the base for this case. It states: "... situated within the boundaries of the TRNC on 15 November 1983, shall be the property of the TRNC notwithstanding the fact that they are not so registered in the books of the Lind Registry Office: and the Land Registry Office shall be amended accordingly". The ECFR in its decision held that Turticy was responsible for the situation of Cyprus on the ground that Turkey invaded Cyprus in 1974, and after that time, the Greek Cypriots could nol get access to their property situated in Northern Cyprus. ${ }^{134}$

In the recent case, Case of Cyprus $v$. Turkey, ${ }^{1+1)}$ which was brought by the Greck Cypriot Administration against Turkey before the ECHR, the Court followed the reasoning of the majority in the Loididou case and found Turkey guilty of human rights violations of the Greek Cypriot people living in the northem part of the Island before the Turkish military invention $100 \mathrm{k}$ place in 1974. Among others. Turkey was found responsible for: fiiling to investigate the deaths of roughly $\$ .500$ people who disappeared in the military invasion. ${ }^{1+1}$ inhuman treatment of the families of missing Greek Cypriots. ${ }^{15-}$ denying some 180.000 Greek Cypriots the right to return to their homes. ${ }^{1.3}$ failure to compensate for loss of property, ${ }^{1+1}$ and interlerence with freedom of religion. ${ }^{15}$ In line with the Loizidou judgement, the legal base for finding Turkey responsible lied on the fact that she exercised effective overall control over northem Cyprus through its military presence there. ${ }^{1+0}$

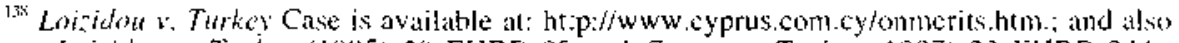

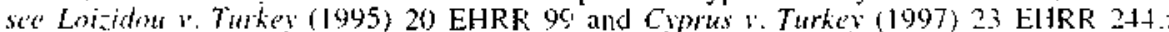
18.12 .1906 ditcd judgment of the ECHR on the Case of Loizidot $r$. Turkey is published in ECHR Reports 1996-VI.

"Lotzdom 1. Therkey paras. 60-64. For the opinion challenging the decosion of the ECHR. see Necatigil. M. Z. "Jutgement of the European Court of Human Rights in the Loizidou Case: A Critical Examination", (1999) 4 Pereeptions. Journal of International Affitis p. 149. In this context, illso sec Ertekun. M.N.M. "The Loizidon Case: A Miscarriage of Justice". (1999) a Perceptions, Joumal of International Alfairs p. 143.

i* Case of Cypus r. Tuke', Judgment, 10.06 .2001

14l Cave of Cipmor r. They para. 136.

14: Hid. pario. 158

1.3. lbid. partal 189

$1+1$ bid, para. 194

145 Hid. púra. 246

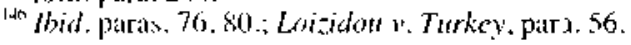


Non-recognition of the TRNC as an independent State by the international community, the resolutions adopted by the UN Security Council and the Council of Europe's Committee of Ministers in this regard were also taken into consideration by the ECHR to justify its findings. ${ }^{147}$

The decisions of the ECHR can be strongly criticised for the following reasons:

Firstly, Turkey's notification relating to the Article 25 of the Convention should have been carefully assessed. It provides that "[t]he recognition of the right of petition extends only to allegations concerning acts or omissions of public authorities in Turkey performed within the boundaries of the territory to which the Constitution of the Republic of Turkey is applicable". Under this reservation, the case did not concern the acts and omissions of Turkey. The TRNC is an independent State and as such, how can Turkey be found responsible for the Cyprus situation? Also, Turkey does not exercise any sovereign rights over the territory of the TRNC. Is it possible for Turkey to be assumed to exercise jurisdiction within the TRNC which has declared its independence? ${ }^{18}$ Even if the TRNC is not recognised by the international community, it is possible to bring an action against the TRNC since it has international personality and is entitled to the rights and duties of international law. ${ }^{1+9}$ The practice of the international community confirms this fact. For example, in the Tinoco Arbitration (Great Britain v. Costa Rica), ${ }^{t o v}$ although Great Britain did not recognise Costa Rica, she made claims against this State. In this arbitration, the arbiter, Judge Thaft held that if an unrecognised body was effective, it was bound by its duties and could be faced with international claims. Similarly, the UK claimed compensation from the unrecognised Taiwan Government (Formosa: Chinese Nationalist Authorities) for damage done to British vessels by Nationalist Forces based in Formosa in $1957 .{ }^{151}$ By virtue of this practice in international law, Mrs. Loizidou could have brought her action against the TRNC, but not against Turkey. The view taken by the ECHR in the Case of Cyprus v. Turkey supports this point and it will be discussed below.

Secondly, concerning the Cyprus issue, Turkey is not solely responsible for the current situation in the Island. The UNFICYP has been settled in

\footnotetext{
${ }^{147}$ Loizidon v. Turkey, paras. 18, 40.; Case of Cyprus v. Turkey, paras. 60-61.

1t Necatigil, Z., M.. "Human Rights in Cyprus", (Autumn 1991) Turkish Review - Quarterly Digest. pp. 19-22.; Entckun, "The Loizidou Case...", p. 146.

1.4 Dixon, p. 112 .

${ }^{151}$ Tinoco Arbitration (Great Britain v. Costa Rica), (1923) I RJAA 369.

15. Lauterpacht, E.. "The Contemporary Practice of the United Kingdon in the Field of International Law-Survey and Comment, IV", (1957)6 ICLQ pp. 507-508.
} 
Cyprus since 1964. The dissenting opinion of Judge Bernhardt joined by Judge Lopes Rocha in the Loizidon case explains this fact as follows: "... it is the existence of the factual borderline, protected by forces under United Nations command, which makes 3 impossible for Greek Cypriots to visit and to stay in their homes and on their property in the northem part of the island. The presence of Turkish troops and Turkey's support of the "TRNC" are important factors in the existing situation; but I feel unable to base a judgement of the European Cout of Human Rights exclusively on the assumption that the Turkish presence is illegal and that Turkey is therefore responsible for more or less everything that happens in Northem Cyprus". ${ }^{52}$ Similarly. the Turkish Cypriots "are prevented from visiting and occupying their property in southern Cyprus. It might even concem citizens of third countries who are prevented from travelling to places where they have property and houses". 153

Thirdly. although the Court in the Loizidou case accepted the legitimacy of certain legal arrangements and transactions, ${ }^{15-4}$ Article 159 (1) (b) of the TRNC Constitution was not accepted as legally valid. The reason for this practice is not clear. Judge Pettiti, in his dissenting opinion, describes this isste in the following terms: "... the Court accepted the validity of measures adopted by the TRNC authorities in the field of civil law, privalte law and the registration of births, deaths and marriages, without specifying what reasons for distinguishing between these branches of law and the law governing the use of property justified its decision". In contrast to this decision, the ECHR in the Case of Cyprus v. Turkey did not deploy the same view and held that "remedies available in the "TRNC" ray be regarded as "domestic renedies" of the respondent State". ${ }^{1.55}$ In other words, Article 159 of the TRNC Constitution governing the use of property was considered as legally valid. ${ }^{1.6}$ Furthermore, the legality of the cotrts of the TRNC for the purposes of adjudicating "civil rights and obligations" is "considered to be "established by law" with reference to the "constiutional and legal basis" on which they operate"157 by the ECHR. While referring to these facts, the ECHR also indicates that this way of implementing international law rules does not mean that the Court recognises the TRNC's claim to statehood ${ }^{15 \%}$ As can be inferred from the rulings of the ECHR, it is clear that the decisions of the

\footnotetext{
152 Dissenting Opinion of Judge Bernhard joined by Judge Lopes Rocha, para. 3. Dissenting Opinion of Judge Pettiti also shares the same view.

15i Disencing Opinion of Judge Goicuklu. para. 4.

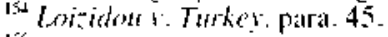

"Sase of Cyptus 2 . Twkey, para. 102. In this context. see Stephen. M. "European Court of Human Rughts Cise of Cyprus $x$. Thrke:" A Critical Analysts". (2001) 6 Perseptions, Journal of International Allairs pp. $126-128$

ish Hid. paris. 89.

15) Hid para 237

19: Hid. para. 238.
} 
Court are not in compliance with each other. From the point of view of international law, the approach taken by the Court in the Case of Cyprusv. Turkey with regard to the acceptance of the remedies available in the TRNC and the legality of the courts of the TRNC should be interpreted as accepting the real situation in the Island and confirming the legal status of the TRNC as an independent State. Although the Court repeats, throughout its decision, that the TRNC is not an independent State and not recognised by the international community the way it deployed in the case does not support its justification. ${ }^{159}$ As having been mentioned above, the recognition of States is a political act and it does not affect the statehood of an entity in international law. The important thing is that whether the entity in question has necessary criterion to be regarded as an independent State. There is no doubt that the TRNC has all qualifications in this respect. The practice of the UK is an example of proving this fact; the effective nature of the administration in the northern part of Cyprus has been recognised in various decisions in the UK despite the fact that it was not recognised by the UK Government. Examples of such cases are, Hesperides Hotels Ltd and another v. Aegean Turkish Holidays Ltd and another, ${ }^{100}$ Polly Peck International plc $v$. Nadir and others $^{\text {tht }}$ and $R v$. The Minister of Agriculture. ${ }^{\text {th2 }}$ In the Hesperides Case, Lord Denning MR assessed the administration in Northern Cyprus as follows: "There is an effective administration in northern Cyprus which made laws governing the day to day lives of the people. According to these laws, the people who have occupied these hotels in Kyrenia are not trespassers. They are not occupying them unlawfully. They are occupying them by virtue of a lease granted to them under the laws or by virtue of requisitions made by the existing administration. If an action were brought in the courts of this northern part, alleging trespass to land or to goods, it would be bound to fail. It follows inexorably that their conduct cannot be made the subject of a suit in England". ${ }^{163}$ This statement was made at the time of the Turkish Federated State of Cyprus Government. (As was previously mentioned, the TRNC was not established until on 15 November 1983). The other mentioned cases above confirmed this view. ${ }^{\text {int }}$

Fourthly, the ECHR does not give sufficient weight to the causes and effects of the events which occurred in Cyprus between 1963 and 1974 ,

\footnotetext{
${ }^{139}$ In this sense, see Partly Dissenting Opinion of Judge Palm joined by Judges Jungwiert, Levits, Pantiru. Kovler and Marcus-Helmons in the Case of Cyprus r. Turkey.

${ }_{1+1}$ Hesperides Hotels Lid and another v. Aegean Turkish Holidass Lid and another. [1978] 1 Ail ER 277.: (1977) 3 WLR 656.; Merrills, J., G.. "Trespass to Foreign Land". (1979) 28 ICLQ pp. 523-525; Warbrick, C.. " The New British Policy on Recognition of the Governments", (1981) 30 JCLQ pp. 582, 585-590.

161 Polly Peck international plc v. Nadir and others, [1992] 4 All ER 769

${ }^{16}$ Not reported, but available in Dixon, pp. 1 16, 122-123.

163 [1978] 1 All ER p. 285.

1a Polly Peck International plc v. Nadir and others [1992] 4 All ER p. 773; For the other case, see Dixon pp. 116. 122-123.
} 
moreover to the developments since the military intervention of Turkey. ${ }^{\text {ln }}$ The judgements of the Court does not deal with the legality of the intervention of Turkish forces in northern Cyprus, which should have been the main isste to deliver any judgement finding Turkey responsible for the current situation. As the international practice confirms, the Turkish military intervention was lawlud and jo canno be seen as aggression in intemational law. ${ }^{\text {fin }}$ To regard the decisions of the ECHR as consistent with the rules of intemational law, the judgenents should have taken into account the Treaty of Guatantec, ${ }^{\text {wi }}$ as one of its consequences the Turkish intervention ${ }^{16 \%}$ and the right of the Turkish Cypriot people to self determination. If' $^{\prime \prime}$ Any judgement ignoring these principies of international law in relation to the Cypres problem must be considered as politically motivaled rather than being levill.

Lastly, the view taken by the ECHR in the Case of Deni-ci and Ohers r. Cypm ${ }^{\text {th }}$ should be noted here. In this judgement, the Court does not again give any weight to the events and factors that is to say that the Turkish Cypriot people either living in the southern part of the Istand or crossing from the morth to the south in order to work there are the victim of amlawfiul and abbitray arrest and delention, victin of inhuman treatment, and of being subject to torture and killings by unknown persons. The only reason to face with such treatment is the ethnic origin of the Turkish Cypriot people. The ECHR in its judgement does not evert imply the existence of such siluations. In the view of the Court, the Turkish Cypriot people living in the south and in the north are the citizens of the Greek Cypriot administration. and the applicants faced with the inhuman teatment, unlaw ful and atbitrary arrest and detemtion. violations of freedom of movements. By applying this understanding into the case, the Grees Cypriot administration is found guilty of human rights violations. In other words, everything was laken into account as if they occurred in one of democratic societies of the world. It does nol look at the fact that the Turkish Cypriots living in the south are subject to discriminatory acts just because of their ethnic origins. In this sense, when the judgements of the ECHR, Loizidon 't. Turke's, Case of Cyprus: Twthey on the one hand, Case of Denizci and Others r. Cypras on the other hand are carefully examined, the international community can witness the one sided application of the rules of international law. Such

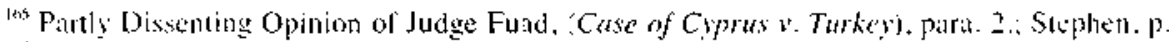
121 .

1(x) hid. pirrá. 5 .

we "So the explanation made under the tite of "The Treaty of Guarantec and International Latw" abouse

${ }_{1+x}$ Ser the explanation made under the itle of "The Legality of the Turkish lutervention" above.

int See the explanation made under the title of "The Right of the Jurkish Cypriot People to Self-Determination" above.

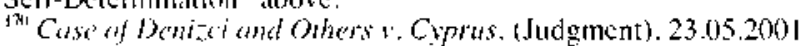


understanding, which ignores the TRNC and its people, and its application by the ECHR in this direction may damage the credibility of the Court.

\section{Conclusions}

As having been mentioned in this paper, since 1963 there has not been a State representing the whole island of Cyprus. The Republic of Cyprus, which was established under the three multilateral treaties (the Treaty of Establishment, the Treaty of Guarantee and the Treaty of Alliance), lasted for only three years after its establishment. The two separate administrations, the Greek Cypriot and the Turkish Cypriot administration, have replaced the Republic of Cyprus. However. the international community has continued to recognise the Greek Cypriot government as the legitimate government of Cyprus. Under these conditions, the Turkish Cypriots had to establish their own states. The Declaration of the TRNC on November 1983 was a natural result of the process of the separate political identification of the Turkish Cypriot community.

When the recent history of Cyprus is examined it can clearly be seen that the legal status of the TRNC is not any less legal than its Greck Cypriot counterpart with regard to its statehood and recognition in international law. The traditional requirements of statehood contained in the Montevideo Convention on the Rights and Duties of States (1933) - which are. a permanent population, a defined territory, an effective government and a capacity to enter into relations with other States (independence) - all exist in the case of the TRNC. An entity which satisfies these conditions is accepted as a State whether its statehood is recognised by the international community or not. Recognition does not affect the concept of statehood according to the declaratory theory which is supported by the major jurists and international practice. The most recent practices of States, in the recognition of the former republics of the Soviet Union and Yugoslavia are proof of the fact that recognition is seen as a political act of the executive branches of States rather than a legal concept.

Any international organisation dealing with the Cyprus problem should bear in mind the aforementioned facts. In this sense, the ECHR should have taken into account the realities of the Cyprus issue in its decisions on the Loizidon v. Turkey. Case of Cyprus v. Turkey and Case of Denizci and Others $v$. Cyprus. Any judgement ignoring the legality of the Turkish intervention, statelood of the TRNC, in other words, the realities of the Island, should be considered as politically motivated rather than being legal in international law. Any judgement accepting the Greek Cypriot administration as representing the whole island of Cyprus on the one hand and ignoring the TRNC and its people on the other hand cannot be justified 
in any international law ground. Sinca the ECHR does not give any weight to the facts which we indicated in this paper its judgements cannot be considered as in compliance with the rules of international law and in particular, with the Treaties that gave birth to the Republic of Cyprus. The approach taken by the ECHR may also damage the credibility of such an infernational institution that delivers landmark decisions in relation to the violations of human rights.

Lastly. it should also be noted that if the ECHR continues to deliver its judgements in the same vein, it does not help to the Cypriot people. eialher Greek or Turkish origin, to reach a final settlement of the Cyprus problen. The view deployed by the Court makes even more difficult to keep both communities in the same negotiation table to find a peaceful solution to the issue. The international community wants to see the Cyprus problem solved and became the whole island as a member of the EU. The ECHR should have also taken this factor into its account before delivering its judgements concerning the Cyprus case. 